Atmos. Chem. Phys. Discuss., https://doi.org/10.5194/acp-2017-928

Manuscript under review for journal Atmos. Chem. Phys.

Discussion started: 27 October 2017

(c) Author(s) 2017. CC BY 4.0 License.

\title{
Global impact of monocyclic aromatics on tropospheric composition
}

\author{
David Cabrera-Perez ${ }^{1}$, Domenico Taraborrelli ${ }^{2}$, Jos Lelieveld ${ }^{1}$, \\ Thorsten Hoffmann ${ }^{3}$, and Andrea Pozzer ${ }^{1}$ \\ ${ }^{1}$ Atmospheric Chemistry Department, Max-Planck Institute of Chemistry, Hahn-Meitner-Weg 1, \\ D-55128 Mainz, Germany \\ ${ }^{2}$ Institute of Energy and Climate Research (IEK-8), Forschungszentrum Jülich GmbH, Jülich, \\ Germany \\ ${ }^{3}$ Institute of Inorganic and Analytical Chemistry, University of Mainz, Duesbergweg 10-14, 55128 \\ Mainz, Germany \\ Correspondence to: D. Cabrera (d.cabrera@mpic.de)
}

\begin{abstract}
Aromatic compounds are reactive species influencing ozone formation, $\mathrm{OH}$ concentrations and organic aerosol formation. An assessment of their impacts on the gas-phase composition at a global scale has been performed using a general circulation atmospheric-chemistry model.

Globally, we found a small annual average net decrease (less than 3\%) in global $\mathrm{OH}$, ozone,

5 and $\mathrm{NO}_{\mathrm{x}}$ mixing ratios when aromatic compounds are included in the chemical mechanism. This inclusion of aromatics also results in $\mathrm{CO}$ mixing ratio increases, which cause a general decrease in $\mathrm{OH}$ concentrations. The largest changes are found in glyoxal and $\mathrm{NO}_{3}$, with increases in the atmospheric burden of $10 \%$ and $6 \%$, respectively.

Regionally, significant differences were found particularly in high $\mathrm{NO}_{\mathrm{x}}$ regime areas, with an increase of up to $4 \%$ in $\mathrm{O}_{3}$ mixing ratios and $8 \%$ in $\mathrm{OH}$ concentrations. $\mathrm{NO}_{3}$ increased by more than $30 \%$ in several regions of the northern hemisphere, and glyoxal increased up to $40 \%$ in Europe and Asia. Large increases in formaldehyde were found in urban areas.

Although the relative impact of aromatics at the global scale is limited, at a regional level they are important in atmospheric chemistry.
\end{abstract}

\section{Introduction}

Volatile organic compounds (VOCs) comprises a large variety of compounds whose oxidation influences the tropospheric chemistry at local, regional, and global scales. The VOC oxidation affects the formation of key atmospheric species, for example $\mathrm{OH}$, which controls the tropospheric oxidative capacity (Levy, 1971; Koppmann, 2008); and ozone, a major atmospheric pollutant with the capability of modifying the climate forcing and toxic for terrestrial life (Lelieveld and Dentener, 2000; Finlayson-Pitts and Pitts, 1997; Forster et al., 2007; Lelieveld et al., 2015). 
Atmos. Chem. Phys. Discuss., https://doi.org/10.5194/acp-2017-928

Manuscript under review for journal Atmos. Chem. Phys.

Discussion started: 27 October 2017

(c) Author(s) 2017. CC BY 4.0 License.

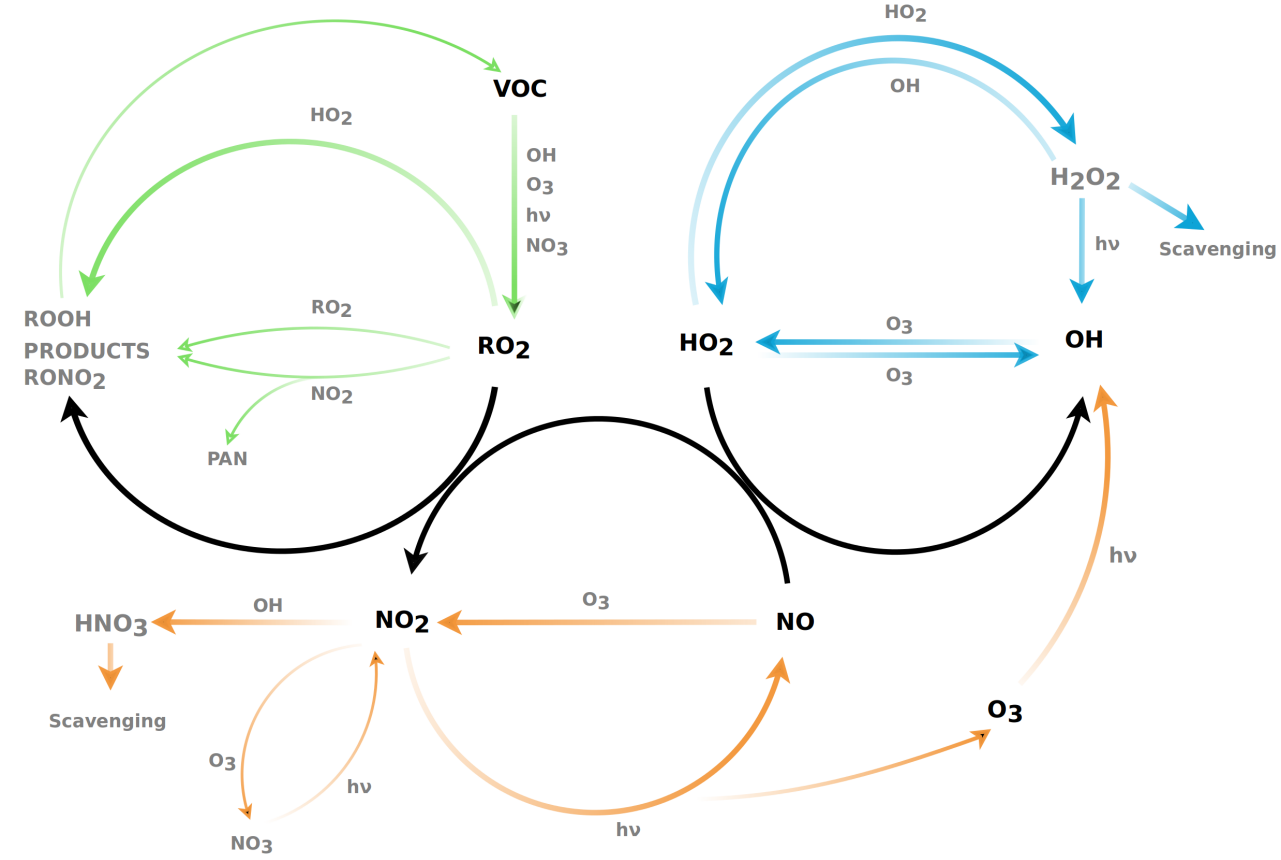

Figure 1. Schematic of the main recycling process of $\mathrm{NO}_{\mathrm{x}}$ (orange), $\mathrm{HO}_{\mathrm{x}}$ (blue), and VOC degradation (green). Black lines denote the interaction between the different cycles.

In general, ozone formation is controlled by the presence of VOCs and $\mathrm{NO}_{\mathrm{x}}\left(\mathrm{NO}+\mathrm{NO}_{2}\right)$. VOCs are oxidized by $\mathrm{O}_{3}, \mathrm{OH}, \mathrm{NO}_{3}$ or photolyzed yielding peroxy radicals $\left(\mathrm{RO}_{2}\right.$ in reaction $\left.\mathrm{R} 1\right)$.

$\mathrm{VOC}+\mathrm{OH} \rightarrow \mathrm{RO}_{2}$

The reaction of $\mathrm{NO}$ either with the hydroperoxyl $\left(\mathrm{HO}_{2}\right)$ or the peroxy radical $\left(\mathrm{RO}_{2}\right)$ produces $\mathrm{NO}_{2}$.

$\mathrm{HO}_{2}+\mathrm{NO} \rightarrow \mathrm{NO}_{2}+\mathrm{OH}$

$\mathrm{RO}_{2}+\mathrm{NO} \rightarrow \mathrm{NO}_{2}+\mathrm{RO}$

The $\mathrm{NO}_{\mathrm{x}}$ cycle is completed by $\mathrm{NO}_{2}$ reacting with $\mathrm{OH}$ to form nitric acid $\left(\mathrm{HNO}_{3}\right)$, which can be scavenged or be subject to slow photodissociation, making $\mathrm{HNO}_{3}$ a relatively long-lived compound and the end of the NO chain (Finlayson-Pitts and Pitts Jr, 1986). The photolysis of $\mathrm{NO}_{2}$ leads to $\mathrm{O}_{3}$ formation and $\mathrm{NO}$ recycling.

$\mathrm{NO}_{2}+\mathrm{h} \nu+\left(\mathrm{O}_{2}\right) \rightarrow \mathrm{O}_{3}+\mathrm{NO}$ 
Atmos. Chem. Phys. Discuss., https://doi.org/10.5194/acp-2017-928

Manuscript under review for journal Atmos. Chem. Phys.

Discussion started: 27 October 2017

(c) Author(s) 2017. CC BY 4.0 License.

(c) (1)
Atmospheric

Chemistry

and Physics

Discussions

$\mathrm{O}_{3}+\mathrm{h} \nu \rightarrow \mathrm{O}\left({ }^{1} \mathrm{D}\right)+\mathrm{O}_{2}$

$\mathrm{O}\left({ }^{1} \mathrm{D}\right)+\mathrm{H}_{2} \mathrm{O} \rightarrow 2 \mathrm{OH}$

The reactions R4-R6 form a major path of ozone formation in the troposphere and the efficiency of

this catalytic process is dependent on the $\mathrm{VOC}$ and $\mathrm{NO}_{\mathrm{x}}$ concentrations and their ratio (Kleinman, 1994).

Simultaneously to the $\mathrm{NO}_{\mathrm{x}}$ cycle, in the $\mathrm{HO}_{\mathrm{x}}\left(\mathrm{HO}_{2}+\mathrm{OH}\right)$ cycle $\mathrm{OH}$ radicals react with $\mathrm{O}_{3}$ to form $\mathrm{HO}_{2}$. The reaction of $\mathrm{O}_{3}$ with $\mathrm{HO}_{2}$ produces $\mathrm{OH}$.

$\mathrm{OH}+\mathrm{O}_{3} \rightarrow \mathrm{HO}_{2}+\left(\mathrm{O}_{2}\right)$

45

$\mathrm{HO}_{2}+\mathrm{O}_{3} \rightarrow \mathrm{OH}+\left(2 \mathrm{O}_{2}\right)$

Self-reaction of $\mathrm{HO}_{2}$ produces $\mathrm{H}_{2} \mathrm{O}_{2}$ (reaction R9), which under photolysis recycles $\mathrm{OH}$ (reaction R10). However, the efficiency of this recycling process is limited because $\mathrm{H}_{2} \mathrm{O}_{2}$ is rapidly scavenged.

$\mathrm{H}_{2} \mathrm{O}_{2}+\mathrm{OH} \rightarrow \mathrm{HO}_{2}+\left(\mathrm{H}_{2} \mathrm{O}\right)$

50

$\mathrm{H}_{2} \mathrm{O}_{2}+\mathrm{h} \nu \rightarrow 2 \mathrm{OH}$

As $\mathrm{HO}_{\mathrm{x}}$ and $\mathrm{NO}_{\mathrm{x}}$ cycles and the VOC degradation are interconnected, changes in VOC concentrations directly affect the balance and feedback between the cycles. A general scheme describing the VOC, $\mathrm{NO}_{\mathrm{x}}$ and $\mathrm{HO}_{\mathrm{x}}$ cycles and how they are interconnected is presented in Fig. 1.

55 In the low $\mathrm{NO}_{\mathrm{x}}$ regime, ozone production is limited by the reactive nitrogen, independent of the VOC concentrations. Under this condition, net ozone loss takes place; this regime can be considered the default regime for low $\mathrm{NO}_{\mathrm{x}}$ environments. In contrast, the high $\mathrm{NO}_{\mathrm{x}}$ regime is limited by the VOC concentration. This regime describes urban environments, which results in net ozone formation.

60 Among VOCs, aromatics are a group of major relevance in urbanized and industrialized environments. In general, aromatic compounds are present in continental areas, and usually high mixing ratios are observed in urban regions (Barletta et al., 2005). Because of their high reactivities, they have relative short lifetimes - ranging from hours to a few days. The emissions are primarily anthropogenic, being mainly fossil fuel combustion and leakage, and solvent as the most important 

role, but can be important at the regional scale (Cabrera-Perez et al., 2016). Biogenic emissions are only relevant for toluene, although recent studies suggest that aromatics from biogenic sources may rival those from fossil fuel (Misztal et al., 2015).

The volatility of aromatic compounds is high, although upon oxidation they present a large source of secondary organic aerosol (SOA) (Odum et al., 1996; Ziemann and Atkinson, 2012). In urban and semi-urban areas aromatic compounds are a group of major importance for tropospheric chemistry, as they are responsible for a considerable fraction of the ozone and SOA formation ( $\mathrm{Ng}$ et al., 2007; Lee et al., 2002; Ran et al., 2009). Furthermore, they are toxic compounds (WMO, 2000) and can affect directly and indirectly human health.

75 The gas phase chemistry of aromatics is relatively well known, as it is supported by laboratory studies and field campaigns (Atkinson et al., 1989; Zou et al., 2003; Jenkin et al., 2003; Baker et al., 2008). Aromatic compound concentrations are controlled by the hydroxyl radical (OH), but they can also react with nitrate $\left(\mathrm{NO}_{3}\right)$ and ozone $\left(\mathrm{O}_{3}\right)$ radicals, for instance styrene, of which the main sink is reaction with nitrate radicals (Atkinson, 2000). The complete oxidation process from the aromatic compounds to its full degradation to $\mathrm{CO}_{2}$ is rather complex, and during this process ozone, nitrates, $\mathrm{NO}_{\mathrm{x}}$ and $\mathrm{HO}_{\mathrm{x}}$ are formed and consumed.

Due to the highly complex chemical degradation of aromatics, numerical models are essential to quantify the impact of these compounds in atmospheric chemistry. However, at the global scale studies concerning the gas-phase atmospheric implication of aromatic compounds are lacking. The main objective of this study is to disentangle how tropospheric $\mathrm{HO}_{\mathrm{x}}, \mathrm{NO}_{\mathrm{x}}, \mathrm{O}_{3}$, and several VOC concentrations are affected globally by the oxidation of aromatic compounds. For this task we use a global atmospheric circulation model and a series of sensitivity simulations.

A detailed description of the model, set-up and scenarios used for this study are described in section 2. Section 3 presents model results for ozone, $\mathrm{OH}$ and VOCs comparing two scenarios and estimating the influence of aromatics. Different sources of error are discussed in sect. 4 followed by the conclusions (sect. 5).

\section{Model set-up}

The model employed for this study is the ECHAM5 MESSy Atmospheric Chemistry (EMAC) model. The Modular Earth Submodel System (MESSy) is a modularized system which allows the representation of atmospheric photo-chemistry, deposition, transport, radiation and cloud atmospheric processes (Jöckel et al., 2010). MESSy (version 2.50) is coupled to the general circulation model ECHAM5 (version 5.3.02) (Roeckner et al., 2006). EMAC is an atmospheric chemistry general circulation model and it has been extensively evaluated (Pozzer et al., 2007, 2010). 
Atmos. Chem. Phys. Discuss., https://doi.org/10.5194/acp-2017-928

Manuscript under review for journal Atmos. Chem. Phys.

Discussion started: 27 October 2017

(c) Author(s) 2017. CC BY 4.0 License.

Table 1. List of aromatic compounds included in this study and the respective annual emissions. This emissions are the same as in (Cabrera-Perez et al., 2016) but for higher aromatics.

\begin{tabular}{lc} 
Species & Emissions $(\mathrm{Tg} / \mathrm{yr})$ \\
\hline Benzene & 8.5 \\
Toluene & 8.7 \\
Xylenes & 6.6 \\
Ethylbenzene & 0.9 \\
Benzaldehyde & 2.5 \\
Phenol & 7.5 \\
Styrene & 0.9 \\
Trimethyl-benzene & 1.6 \\
Higher aromatics & 3.8 \\
Total & 39.2 \\
\hline
\end{tabular}

In this work a resolution of T63L31ECMWF was used, which corresponds to a horizontal resolution of $1.875^{\circ} \times 1.875^{\circ}$ and a vertical resolution of 31 hybrid-pressure levels, extending up to the tropopause. The simulated period covers the years 2004-2005, with the first year being used as spinup, and the year 2005 being used for the analysis. The feedback between radiation and chemistry was decoupled to avoid any influence of chemistry on the dynamics (QCTM mode (Deckert et al., 2011)). As a consequence, every simulation discussed here has identical meteorology (i.e. binary identical transport).

To analyze the influence of aromatic compounds on atmospheric composition, we performed a comparison between two scenarios. The baseline scenario, called REF scenario, excludes the emissions of aromatic compounds. The second scenario, called AROM scenario, includes all emissions from anthropogenic, biogenic, and biomass burning sources of the following aromatic compounds:

110 benzene, toluene, xylenes (lumped), phenol, styrene, ethylbenzene, trimethylbenzenes (lumped), benzaldehydes, and higher aromatics (as representative of aromatics with more than nine carbon atoms). Both scenarios are identical aside from emissions (in the baseline case there is no chemistry of aromatic species).

We used the Representative Concentration Pathways (RCP) inventory for anthropogenic emissions (van Vuuren et al., 2011), distributed vertically as in (Pozzer et al., 2009); the MEGAN model for biogenic emissions, (Guenther et al., 2012), and the MESSy submodel Bioburn—which integrates the Global Fire Assimilation system (GFAS) inventory (Kaiser et al., 2012)—for biomass burning. In the AROM scenario, emissions are identical to those in Cabrera-Perez et al. (2016), except for the emissions of higher aromatics. In this work, emissions of higher aromatics were expanded to include biomass burning emissions. Emissions of aromatics sum to $35 \mathrm{TgC} / \mathrm{yr}$, of which 3.4 
$\mathrm{TgC} / \mathrm{yr}$ are higher aromatics (the details of the emission factors used can be found in the supplement doi:10.5194/acp-0-1-2017-supplement). The atmospheric oxidation of aromatic compounds is performed by the MECCA sub-model (Sander et al., 2011). The complete description of the model setup-including emissions, the chemical mechanism used, and the evaluation of the AROM scenario-are included in Cabrera-Perez et al. (2016).

The products from the oxidation of aromatic compounds have reduced volatility, allowing them to partition into the aerosol phase and form SOA. This removal process of aromatic trace gases can significantly reduce the mixing ratios of the aromatic oxidation products. Since SOA formation is outside the scope of this work, additional channels in the chemical mechanism have been added to account for loss via SOA formation after the first oxidation step, using the yields from $\mathrm{Ng}$ et al. (2007). The modifications in the chemical mechanism are described in the supplement (doi:10.5194/acp-01-2017-supplement). This approach avoids a possible overestimation of atmospheric concentrations of aromatic oxidation products but simultaneously limits the possible impact of aromatics products on the gas-phase chemistry.

\section{Results/ Results discussion}

Figure 2 shows the annual average mixing ratios of the sum of all aromatic compounds included in the numerical simulation. The mixing ratios are higher in continental areas and close to the surface. The highest mixing ratios are found in East and South Asia, as well as in parts of Europe and the US, reaching up to ppb levels. The background mean mixing ratios in oceanic areas of the Southern Hemisphere are on the order of a few ppt.

In this section we compare the AROM scenario to the baseline $R E F$ scenario (i.e. AROM-REF).

\subsection{Hydroxyl radical $(\mathrm{OH})$}

Figure 3 (upper right) shows the relative difference (in \%) in annually averaged daytime $\mathrm{OH}$ surface concentrations between the REF and AROM scenarios. Eastern Asia, Europe, and the east coast of the US show increased $\mathrm{OH}$ concentrations. The fractional increase in $\mathrm{OH}$ is up to $8 \%$ in Eastern Asia, 6\% in Europe, and 4\% in the US. Comparing the $\mathrm{OH}$ concentrations (Figure 3, upper left) with the relative and absolute differences, we notice that regions with the maximum (relative and absolute) difference (Figure 3, upper right and bottom left) match the territories where $\mathrm{OH}$ is quickly recycled in the atmosphere, as a result of the large anthropogenic VOC emissions in the presence of $\mathrm{NO}_{\mathrm{x}}$. Everywhere else, we find a net depletion of $\mathrm{OH}$. Indonesia and its surrounding areas, and continental areas on the equatorial belt both have the strongest $\mathrm{OH}$ depletion. During the day in the northern hemisphere the relative differences of the annual zonal mean (Fig. 3, bottom right) globally decreases, with a (negative) gradient towards the free troposphere, reaching the maximum decrease at 200-300 hPa. 
Atmos. Chem. Phys. Discuss., https://doi.org/10.5194/acp-2017-928

Manuscript under review for journal Atmos. Chem. Phys.

Discussion started: 27 October 2017

(c) Author(s) 2017. CC BY 4.0 License.
Atmospheric

Chemistry

and Physics

Discussions

(c) (1)
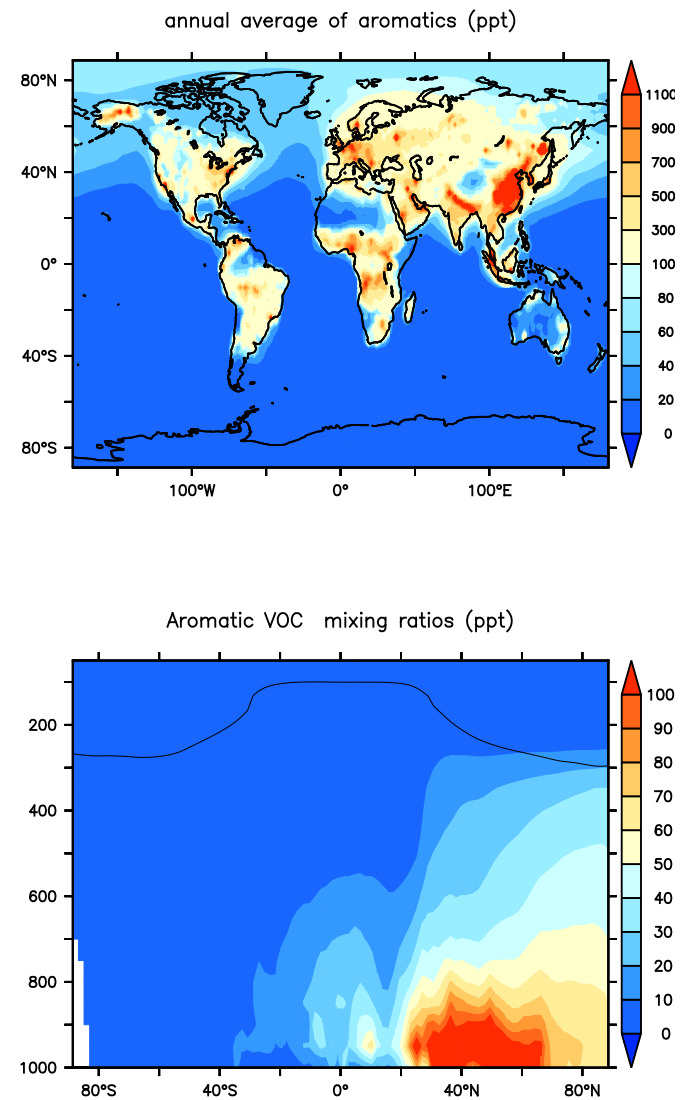

Figure 2. Top, annual mean of surface mixing ratios of the sum of aromatics. Bottom, zonal annual mean. Units are ppt.

155 During the night, an increase up to $6 \%$ is found between $800-600 \mathrm{hPa}$ in the northern hemisphere. At the surface, annual average $\mathrm{OH}$ concentrations decrease in Europe, the US and Eastern Asia due to its reactions with organics. The largest absolute differences are a decrease of $1 \times 10^{3} \mathrm{mlc} / \mathrm{cm}^{3}$ in India and Central Africa (approximately 6-10\%). Nevertheless, due to the limited oxidation capacity and influence of $\mathrm{OH}-$ on $\mathrm{CH}_{4}$ and $\mathrm{CO}$-at night (Lelieveld et al., 2016), we consider that these changes are of less relevance than the changes found during the day.

The maximum instantaneous $\mathrm{OH}$ differences at the surface during the day exceeds $100 \%$ in the northern hemisphere continental areas during the winter, spring, and fall seasons, with absolute differences larger than $20 \times 10^{5} \mathrm{mlc} / \mathrm{cm}^{3}$ in Eastern China and Central Africa. 
Atmos. Chem. Phys. Discuss., https://doi.org/10.5194/acp-2017-928

Manuscript under review for journal Atmos. Chem. Phys.

Discussion started: 27 October 2017

(c) Author(s) 2017. CC BY 4.0 License.
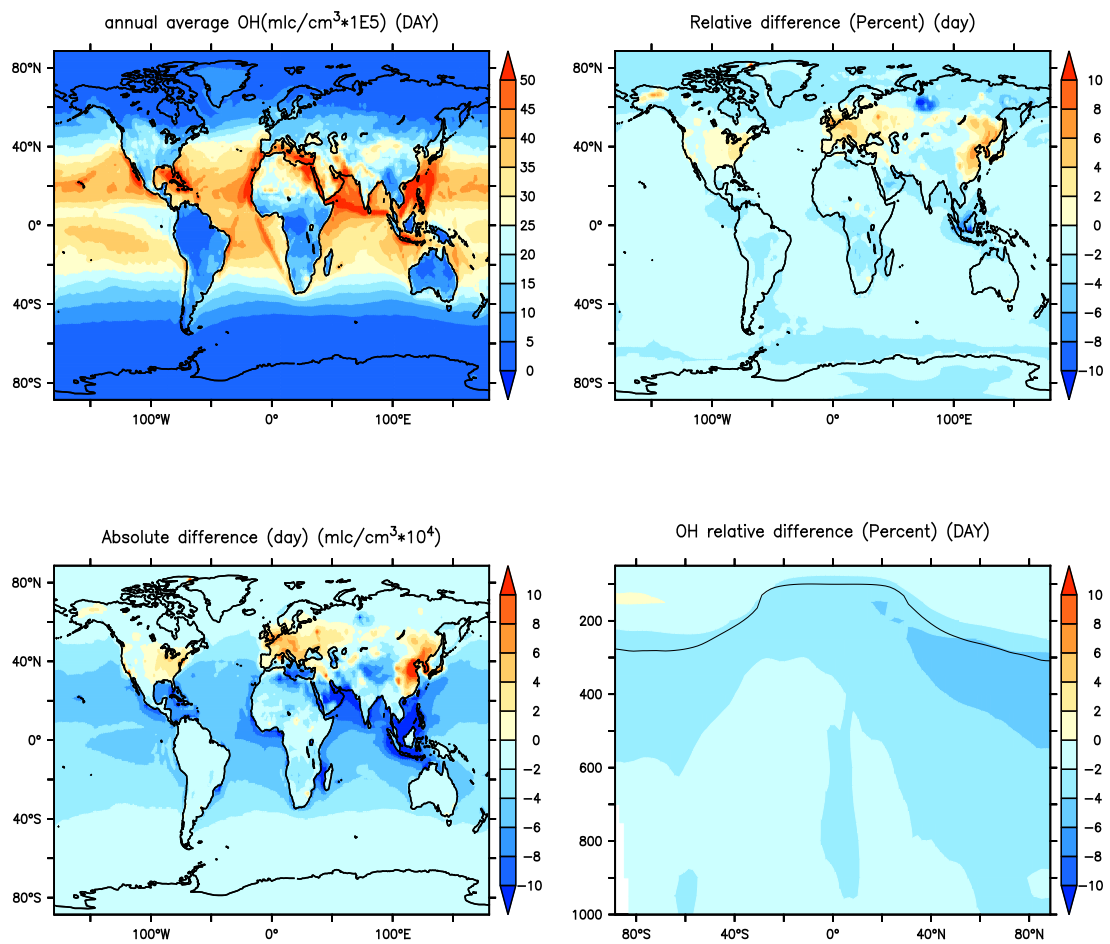

Figure 3. On the upper left panel, annual average surface concentrations of $\mathrm{OH}$ during day time ( $R E F$ scenario). On the upper right, surface $\mathrm{OH}$ relative difference between aromatic and no-aromatic scenarios expressed in $\%$. On the lower left, $\mathrm{OH}$ absolute difference between mentioned scenarios. On the lower right, zonal relative differences (in \%).

On the seasonal level, higher $\mathrm{OH}$ concentrations are found over continental areas during the winter and spring than in summer and autumn (see doi:10.5194/acp-0-1-2017-supplement). During the daytime in northern hemisphere winter the relative increase in $\mathrm{OH}$ exceeds $50 \%$ (e.g. China and Europe). These differences correspond to absolute increases of approximately $20 \times 10^{4} \mathrm{mlc} / \mathrm{cm}^{3}$ in China and West Asia, and of less than $6 \times 10^{4} \mathrm{mlc} / \mathrm{cm}^{3}$ in the US and, Europe. In summer, Europe is the only region where $\mathrm{OH}$ concentrations increase when aromatics are included, although not exceeding $5 \%$. The increase of $\mathrm{OH}$ production via $\mathrm{NO}+\mathrm{RO}_{2}$ through the increase of $\mathrm{RO}_{2}$ concentrations are due to aromatics oxidation. Although there is a ubiquitous decrease in $\mathrm{NO}_{\mathrm{x}}$, this does not seem to limit $\mathrm{OH}$ formation. In the southern hemisphere and in oceanic areas the net effect of introducing aromatic compounds into the system results in a net depletion of $\mathrm{OH}$ due to the increase of $\mathrm{CO}$ as final product of the oxidation scheme (see Sect. 3.5.3). Figure 5 shows the seasonal cycle 
Atmos. Chem. Phys. Discuss., https://doi.org/10.5194/acp-2017-928

Manuscript under review for journal Atmos. Chem. Phys.

Discussion started: 27 October 2017

(c) Author(s) 2017. CC BY 4.0 License.
Atmospheric

Chemistry

and Physics

Discussions

(c) (1)
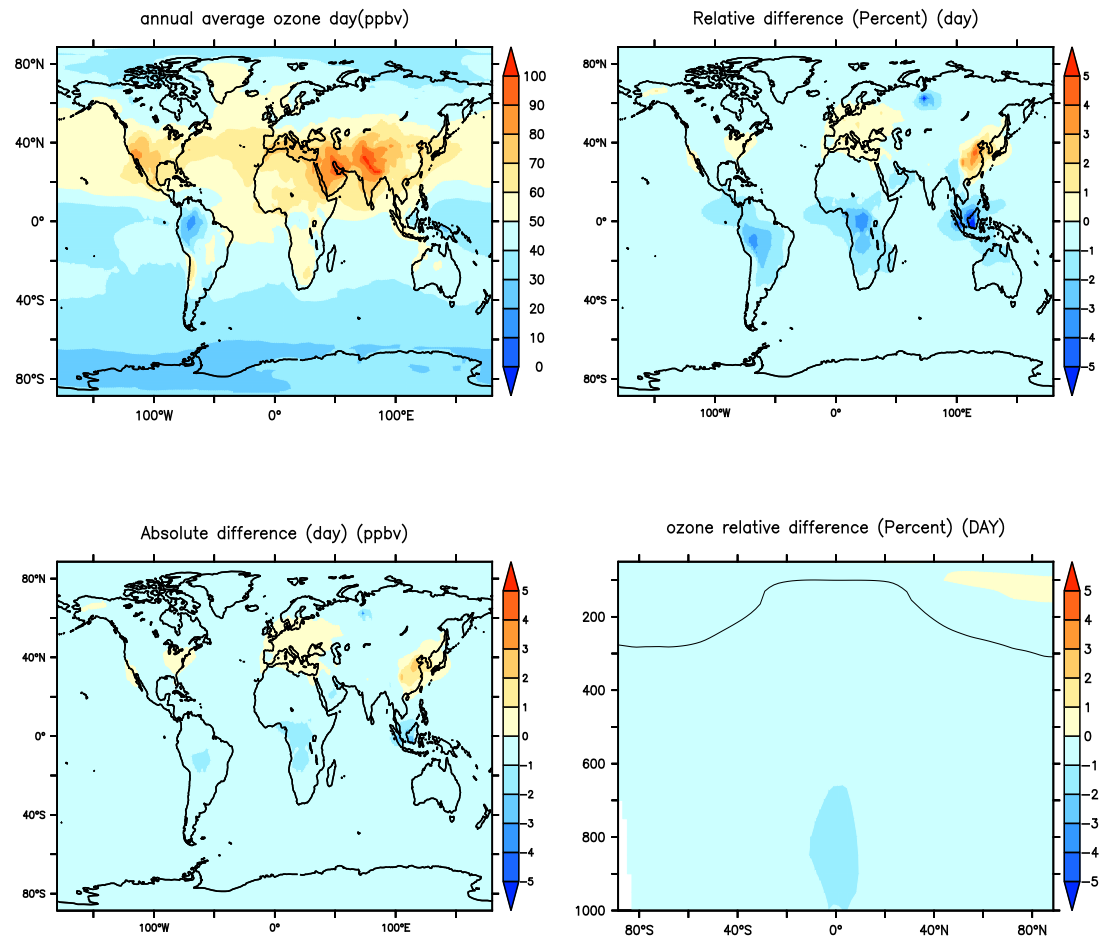

Figure 4. On the upper left panel, annual average surface mixing ratios of $\mathrm{O}_{3}$ during day time (REF scenario). On the upper right, surface $\mathrm{OH}$ relative difference between aromatic and no-aromatic scenarios expressed in $\%$. On the lower left, $\mathrm{OH}$ absolute difference between mentioned scenarios. On the lower right, zonal relative differences (in \%).

of the relative difference between both scenarios for the northern and southern hemispheres. We find that the relative difference varies between $-3.5 \%$ for winter months up to $-1.5 \%$ in summer months. The cycle is reversed for the southern hemisphere, where the changes in $\mathrm{OH}$ concentrations are due to transported species (mostly CO), making changes relatively homogeneous.

Table 2 lists the $\mathrm{OH}$ concentrations for the REF and AROM scenarios, and the relative and absolute difference averaged globally in the boundary layer. We obtain an enhancement of $2-3 \%$ in the atmospheric lifetime of methane, along with a decrease in $\mathrm{OH}$ concentration. Methane is a longlived species whose breakdown is driven by $\mathrm{OH}$ (Crutzen and Zimmermann, 1991); its lifetime is a measure of the $\mathrm{OH}$ concentration (Prather and Spivakovsky, 1990). The decrease in the $\mathrm{OH}$ concentration thus explains methane's increased lifetime. $\mathrm{OH}$ concentrations are also in line with values estimated by Lawrence et al. (2001), although estimated methane lifetimes are shorter, as 

close to literature estimates: The REF scenario yields a methane lifetime of 9.74 years, and AROM a methane lifetime of 10.05 years, however, this does not include $\mathrm{CH}_{4}$ loss in the stratosphere and from soil uptake, which reduce the overall lifetime of methane. Literature estimates vary between 7.1 and 10.6 years (Voulgarakis et al., 2013; Lawrence et al., 2001). Separating day and nighttime, the the $\mathrm{OH}$ concentration decrease approximately $2 \%$ and $1 \%$-independent of the weighting method-, respectively.

The changes in $\mathrm{OH}$ concentrations are dependent on to the $\mathrm{NO}_{\mathrm{x}}$ regimes, in combination with increases in $\mathrm{CO}$ concentrations and changes in VOC mixing ratios as a consequence of aromatic oxidation. In areas with high $\mathrm{NO}_{\mathrm{x}}$ and $\mathrm{VOC}$ mixing ratios, ozone is formed, which under photolysis produces $\mathrm{OH}$ (R5-R6 ). In contrast, in regions with low $\mathrm{NO}_{\mathrm{x}}$ concentrations or absent anthropogenic emissions $\mathrm{OH}$ recycling is limited by $\mathrm{NO}_{\mathrm{x}}$, forcing the aromatic oxidation products to react with $\mathrm{HO}_{2}$ or peroxy radicals $\left(\mathrm{RO}_{2}\right)$. At the same time, $\mathrm{CO}$ is formed from the oxidation of aromatics (its main sink is reaction with $\mathrm{OH}$ ), strengthening the removal of $\mathrm{OH}$. Moreover, the oxidation chain of aromatics includes a large number of reactions involving $\mathrm{OH}$. Therefore, positive changes in $\mathrm{OH}$ concentrations take place in continental areas with large $\mathrm{NO}_{\mathrm{x}}$ emissions, unlike, for example oceanic areas, where $\mathrm{NO}_{\mathrm{x}}$ concentrations are low.

For $\mathrm{HO}_{2}$ a relative decrease of less than $1 \%$ in the atmospheric global burden is found. At the regional scale, only Europe and East Asia have relative increases in surface mixing ratios by more than $10 \%$. The oxidation of carbon monoxide by $\mathrm{OH}$ is the main source of $\mathrm{HO}_{2}$ (Lightfoot et al., 1992), serving as a buffer for OH; in addition, aromatic chemistry contains a large number of reactions leading to formation of $\mathrm{HO}_{2}$ (e.g. the initial reactions of benzene $+\mathrm{OH}$ leads to Phenol $+\mathrm{HO}_{2}$ ). The updated benzaldehyde photolysis used in this study was also more efficient than the one previously used, making it a significant source of $\mathrm{HO}_{2}$ radicals. The small impact of aromatics observed on the $\mathrm{HO}_{\mathrm{x}}$ budget was expected, since this budget is well buffered against perturbations (Montzka et al., 2011; Lelieveld et al., 2016).

Contrary to expectations, we found large increases of HONO mixing ratios in continental areas, generally with the sign of this change opposite to that of $\mathrm{OH}$. These relative changes reached more than 50\%, specifically in Africa, South-America, the Arabian Peninsula and South-East Asia. The reason for this pattern is explained by the photolysis of nitrophenols, which leads to HONO formation (Bejan et al., 2006; Cheng et al., 2009). In the AROM scenario, approximately $5.7 \%$ of the HONO formation is directly related to nitrophenol photolysis at surface. Nevertheless, the net effect on the atmospheric burden is a depletion of around $1.5 \%$.

\subsection{Ozone}

220 Differences between $A R O M$ and $R E F$ of daytime annual averages of surface ozone mixing ratios are shown in Fig. 4 (upper right and bottom left). In general, surface ozone depletion occurs over large 
Atmos. Chem. Phys. Discuss., https://doi.org/10.5194/acp-2017-928

Manuscript under review for journal Atmos. Chem. Phys.

Discussion started: 27 October 2017

(c) Author(s) 2017. CC BY 4.0 License.

Table 2. Estimated global averaged $\mathrm{OH}$ concentrations in the boundary layer by three different approximations Lawrence et al. (2001) and global lifetimes of methane. Calculations for the reference scenario and the aromatics scenario and the differences between them.

\begin{tabular}{|c|c|c|c|c|}
\hline & $\begin{array}{c}\text { Lifetime } \mathrm{CH}_{4} \\
\text { (years) }\end{array}$ & $\begin{array}{c}\text { OH concentration } \\
(\mathrm{VOL}) \times 10^{6} \mathrm{mlc} / \mathrm{cm}^{3}\end{array}$ & $\begin{array}{c}\text { OH concentration } \\
\text { (MASS) } \times 10^{6} \mathrm{mlc} / \mathrm{cm}^{3}\end{array}$ & $\begin{array}{c}\mathrm{OH} \text { concentration } \\
(\mathrm{CH} 4) \times 10^{6} \mathrm{mlc} / \mathrm{cm}^{3}\end{array}$ \\
\hline & \multicolumn{4}{|c|}{ No aromatics } \\
\hline Global & 4.45 & 1.30 & 1.27 & 1.46 \\
\hline Global day & 2.46 & 2.33 & 2.29 & 2.58 \\
\hline \multirow[t]{2}{*}{ Global night } & 236 & 0.03 & 0.02 & 0.03 \\
\hline & \multicolumn{4}{|c|}{ Aromatics } \\
\hline Global & 4.53 & 1.28 & 1.25 & 1.43 \\
\hline Global day & 2.51 & 2.29 & 2.24 & 2.53 \\
\hline \multirow[t]{2}{*}{ Global night } & 235 & 0.03 & 0.02 & 0.03 \\
\hline & \multicolumn{4}{|c|}{ Relative Difference (\%) } \\
\hline Global & 1.91 & -1.87 & -1.86 & -1.88 \\
\hline Global day & 1.95 & -1.89 & -1.88 & -1.90 \\
\hline \multirow[t]{2}{*}{ Global night } & 0.21 & 0.51 & 0.56 & .20 \\
\hline & \multicolumn{4}{|c|}{ Absolute Difference $\left(10^{4} \mathrm{mlc} / \mathrm{cm}^{3}\right)$} \\
\hline Global & 0.08 & -2.42 & -2.37 & -4.10 \\
\hline Global day & 0.05 & -4.40 & -4.30 & -7.25 \\
\hline Global night & -0.50 & 0.01 & 0.01 & $<0.01$ \\
\hline
\end{tabular}

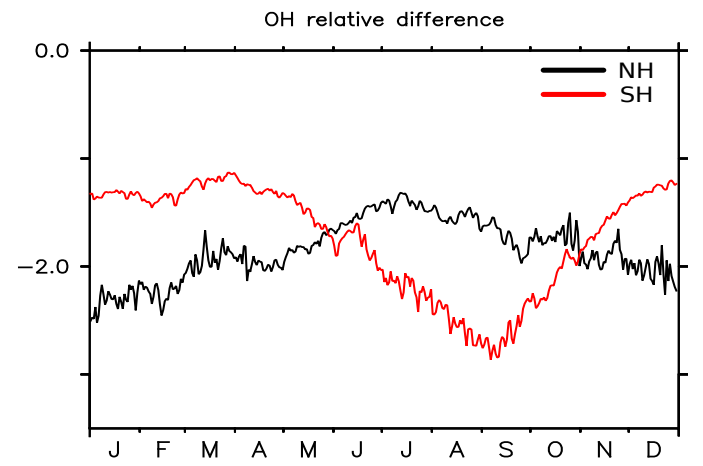

Figure 5. OH relative difference (expressed in percent) in the boundary layer between the AROM and REF scenarios. In black, values for the northern hemisphere. In red, values for the southern hemisphere. 
Atmos. Chem. Phys. Discuss., https://doi.org/10.5194/acp-2017-928

Manuscript under review for journal Atmos. Chem. Phys.

Discussion started: 27 October 2017

(c) Author(s) 2017. CC BY 4.0 License.

(c) (i)

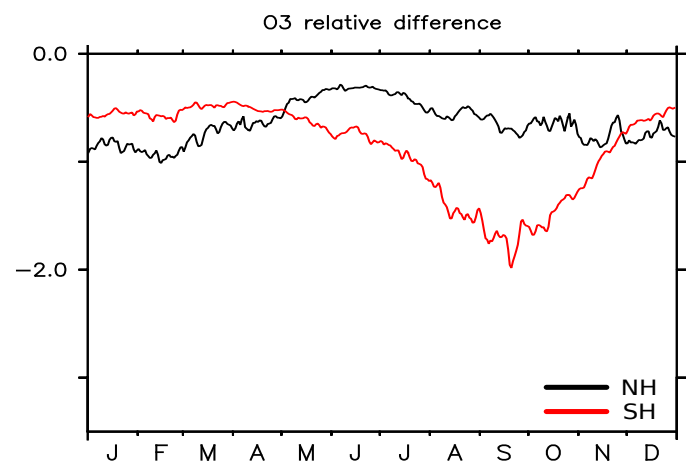

Figure 6. Same as in Fig. 5 for ozone.

Table 3. Estimated global averaged ozone mixing ratios in the boundary layer Lawrence et al. (2001). Calculations for the reference and aromatic scenarios.

\begin{tabular}{lc} 
& $\mathrm{O}_{3}$ mixing ratio ppt \\
\hline Global & No aromatics \\
Global day & 1.11 \\
Global night & 1.05 \\
& 1.18 \\
Global & Aromatics \\
Global day & 1.10 \\
Global night & 1.05 \\
& 1.17 \\
Global & Relative Difference (\%) \\
Global day & -0.72 \\
Global night & -0.57 \\
& -1.76 \\
Global & Absolute Difference (ppt) \\
Global day & -0.69 \\
Global night & -0.63 \\
\hline
\end{tabular}

areas of the globe. Maximum depletion occurs in equatorial areas, of between $10^{\circ} \mathrm{N}-20^{\circ} \mathrm{S}$ (down to $4 \%$, a drop of approximately 5 ppbv). In contrast, some regions of Europe and China have small increases (less than 5\%); these areas match the regions with the largest $\mathrm{NO}_{\mathrm{x}}$ annual mean mixing 
ratios. In Central African and Indonesian territories, where strong biomass burning takes place (i.e. large emissions of VOCs), significant decreases in ozone formation are observed.

No significant differences between daytime and nighttime surface ozone mixing ratios were found, due to the relatively long lifetime of ozone (about three weeks), which is several times longer than the lifetime of aromatics (Stevenson et al., 2006). On the other hand, larger relative differences at the surface are found during part of the year. During the winter months, a relative increase of more than $10 \%$ is found in China, and of $1-4 \%$ in Europe and the US. China had increased ozone mixing ratios for almost the entire year (excluding the summer months), and ozone depletion in central Africa remains relatively constant year-round. During the summer and fall seasons, the strongest depletion is observed in the southern hemisphere (approximately 7\%).

The seasonal distribution of the relative differences (Fig. 6) shows lower amplitude than for $\mathrm{OH}$, but similar patterns. In the northern hemisphere, greater relative differences occurred between scenarios in the winter months than in the summer months; in the southern hemisphere this pattern is reversed. The relative differences range within $1 \%-2 \%$. In the southern hemisphere a maximum difference of $2 \%$ is found over biomass burning activity regions.

240 Maximum increases of ozone of more than $10 \%$ occur over the northern hemisphere. In the US, Europe, and China ozone mixing ratios can increase by more than $20 \%$. Large peaks were also observed in Central Africa, due to strong biomass-burning events.

Relative changes in tropospheric ozone were found to be homogeneous within the northern hemisphere (Fig. 4, bottom right). There did not appear to be any differences between day and night, with decreases below $2 \%$ in the boundary layer and lower part of the free troposphere (up to $7 \mathrm{~km}$ ). Above $7 \mathrm{~km}$ height, the relative differences decrease.

Table 3 presents annual global mean ozone mixing ratios in the boundary layer for both scenarios-weighted by two different methods, but only mass weighted is shown, as both methods lead to the same results - as well as the relative and absolute differences. Both methods show good agreement in the mixing ratios. Relative differences are approximately $1 \%$. During nighttime, relative differences increase to $1.8 \%$. Compared to $\mathrm{OH}$, relative differences are lower for ozone, suggesting that ozone chemistry is less affected by aromatics than $\mathrm{OH}$.

The simulation results show a weakening in the ozone formation; this result brings an interestingly mismatch with former studies (e.g.Butler et al. (2011)). Aromatics, especially toluene and xylenes, have significant ozone formation potentials among VOCs. It could therefore be expected an overall increase in ozone formation when aromatics are introduced into the system. However, there are important differences between the work by (Butler et al., 2011) and this work; the first is based on a box model study for two cities, and the current work focuses on the global scale. It is not clear whether the first work takes into account the dry deposition and scavenging, which can be important factors. Last, the capability of the global model to represent correctly the chemistry in cities is limited due to the coarse model resolution. The ozone depletion in the this model study 
Atmos. Chem. Phys. Discuss., https://doi.org/10.5194/acp-2017-928

Manuscript under review for journal Atmos. Chem. Phys.

Discussion started: 27 October 2017

(c) Author(s) 2017. CC BY 4.0 License.
Atmospheric

Chemistry

and Physics

Discussions

is due to (i) the decrease in $\mathrm{NO}_{\mathrm{x}}$ mixing ratios -limiting ozone formation-, and to (ii) increasing radical production $\left(\mathrm{OH}, \mathrm{HO}_{2}\right.$, and $\left.\mathrm{RO}_{2}\right)$ in ozone-depleting regimes, which enhances reactions of $\mathrm{O}_{3}$ with $\mathrm{HO}_{2}$ and $\mathrm{OH}$. Growth in ozone mixing ratios is observed in regions of high $\mathrm{NO}_{\mathbf{x}}$ mixing ratios, where the limiting factor for ozone formation is hydrocarbon mixing ratios.

\section{3 $\quad \mathrm{NO}_{\mathrm{x}}$}

The simulated annual mean $\mathrm{NO}_{\mathrm{x}}$ mixing ratios at surface were slightly lower in the AROM scenario than in the $R E F$ scenario at surface. One reason of decreased $\mathrm{NO}_{\mathrm{x}}$ is the addition of chemical species containing nitrogen (e.g. nitrophenols) in the AROM scenario, thereby transferring part of the $\mathrm{NO}_{\mathrm{x}}$ burden to the nitrogenated species. Thus, aromatic nitrogenated species become intermediates for the deposition of nitrogen.

The comparison between the $A R O M$ and the $R E F$ model results shows significant $\mathrm{NO}_{\mathrm{x}}$ depletion in central Africa, the Amazon forest, China, and Indonesia, with relative differences reaching approximately $10 \%$ (Fig. 7). In Europe, the US, and the Arabian Peninsula, reductions in $\mathrm{NO}_{\mathrm{x}}$ mixing ratios did not exceed 5\%. Oceanic areas show small decreases, although $\mathrm{NO}_{\mathrm{x}}$ mixing ratios are several orders of magnitude lower than over continental territories, with absolute changes not exceeding 1 ppt. In the boundary layer, $\mathrm{NO}_{\mathrm{x}}$ mixing ratios decreased by $5 \%$ in the AROM scenario.
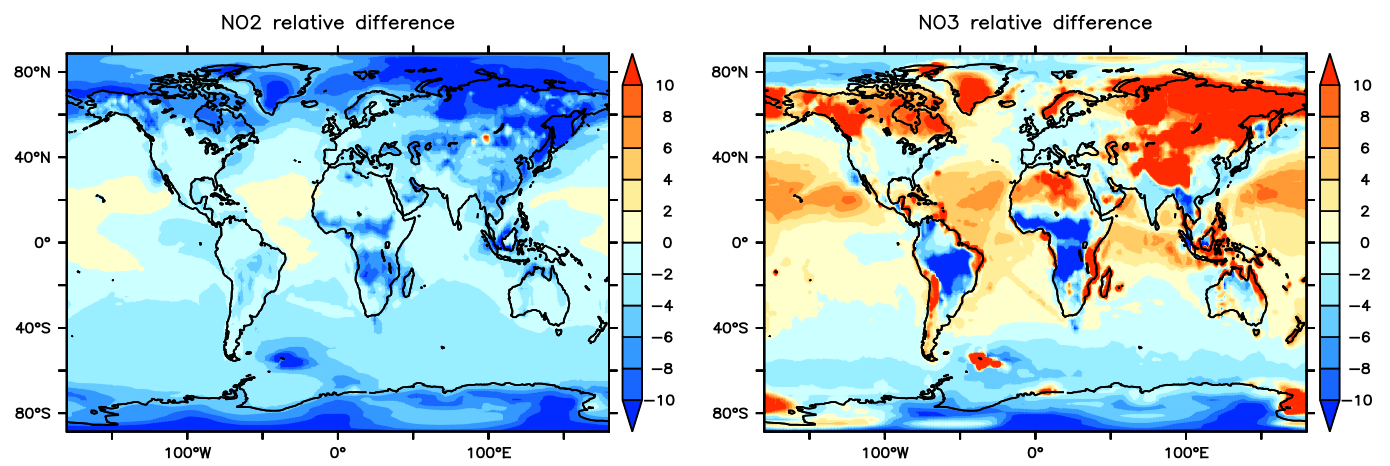

Figure 7. Same as in Fig. 5 for $\mathrm{NO}_{2}$ (left) and $\mathrm{NO}_{3}$ (right).

\section{$3.4 \mathrm{NO}_{3}$ and $\mathrm{HNO}_{3}$}

For annual average boundary layer $\mathrm{NO}_{3}$ mixing ratios we find a global increase of $3 \%$ during nighttime and $6 \%$ during the daytime.

At the regional scale, the largest daytime changes occur in northern Africa, the Arabian Peninsula, and northern Asia, with increases of $20-30 \%$. An increase of more than $30 \%$ was also observed over 
Atmos. Chem. Phys. Discuss., https://doi.org/10.5194/acp-2017-928

Manuscript under review for journal Atmos. Chem. Phys.

Discussion started: 27 October 2017

(c) Author(s) 2017. CC BY 4.0 License.
Atmospheric

Chemistry

and Physics

Discussions

(c) (i)
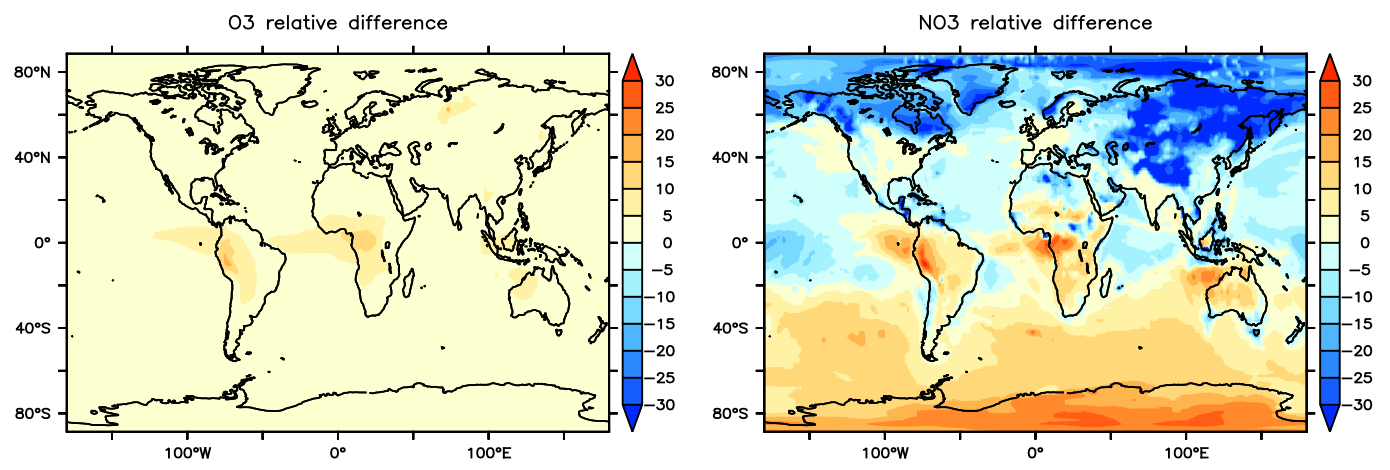

Figure 8. Relative difference ((No phenoxy channel-AROM) / AROM) expressed as a percent for ozone (left) and $\mathrm{NO}_{3}$ (right).

the Tibetan plateau, although mixing ratios in this area are generally low. Decreases of up to $10 \%$ were observed in central Africa and in the Amazonian areas. Since $\mathrm{NO}_{3}$ concentrations are low during daytime, these changes do not significantly affect atmospheric chemistry.

During nighttime, the difference between the scenarios are larger, with a $30 \%$ decrease in mixing ratios in central Africa and the Amazonian areas, an increase of more than $30 \%$ in the Tibetan plateau and northern Asia, and no change in northern Africa.

The net formation or depletion is defined by the competition between the amount of aromatic products consuming $\mathrm{NO}_{3}$ versus the strength of the phenylperoxy channel, which leads to $\mathrm{NO}_{3}$ formation. We investigated the importance of the phenylperoxy channel for $\mathrm{O}_{3}$ and $\mathrm{NO}_{3}$ mixing ratios. The different channels, based on the work of Jagiella and Zabel (2007), were added to the current mechanism (Cabrera-Perez et al., 2016). Figure 8 shows the comparison for $\mathrm{O}_{3}$ and $\mathrm{NO}_{3}$ between the $A R O M$ scenario and an identical scenario without the phenoxy radical channels. Ozone mixing ratios increased as a result of neglecting the channel that transforms $\mathrm{NO}_{2}$ into $\mathrm{NO}_{3}$, and more $\mathrm{NO}_{2}$ is therefore available for the catalytic process leading to ozone formation. The phenylperoxy channels quickly convert $\mathrm{NO}_{2}$ into $\mathrm{NO}_{3}$ (e.g. $\mathrm{C}_{6} \mathrm{H}_{5} \mathrm{O}_{2}+\mathrm{NO}_{2}$ leads to $\mathrm{C}_{6} \mathrm{H}_{5} \mathrm{O}+\mathrm{NO}_{3}$ in the mechanism). For $\mathrm{NO}_{3}$ the areas with increases in the mixing ratios can be explained by the increases in ozone and $\mathrm{NO}_{2}$ mixing ratios, leading to an increase in the $\mathrm{NO}_{3}$ formation. These increases reach up to $30 \%$ in equatorial regions. In contrast, there are regions showing decreases by more than $30 \%$ in $\mathrm{NO}_{3}$ mixing ratios; these decreases suggest a large strength of the phenylperoxy channels in certain areas of the northern hemisphere.

For $\mathrm{HNO}_{3}$, the atmospheric burden decreases by $1 \%$ in the $A R O M$ scenario. However, surface mixing ratios showed increases up to $20 \%$ in East and South-East Asia, Central Africa and South 
Atmos. Chem. Phys. Discuss., https://doi.org/10.5194/acp-2017-928

Manuscript under review for journal Atmos. Chem. Phys.

Discussion started: 27 October 2017

(c) Author(s) 2017. CC BY 4.0 License.
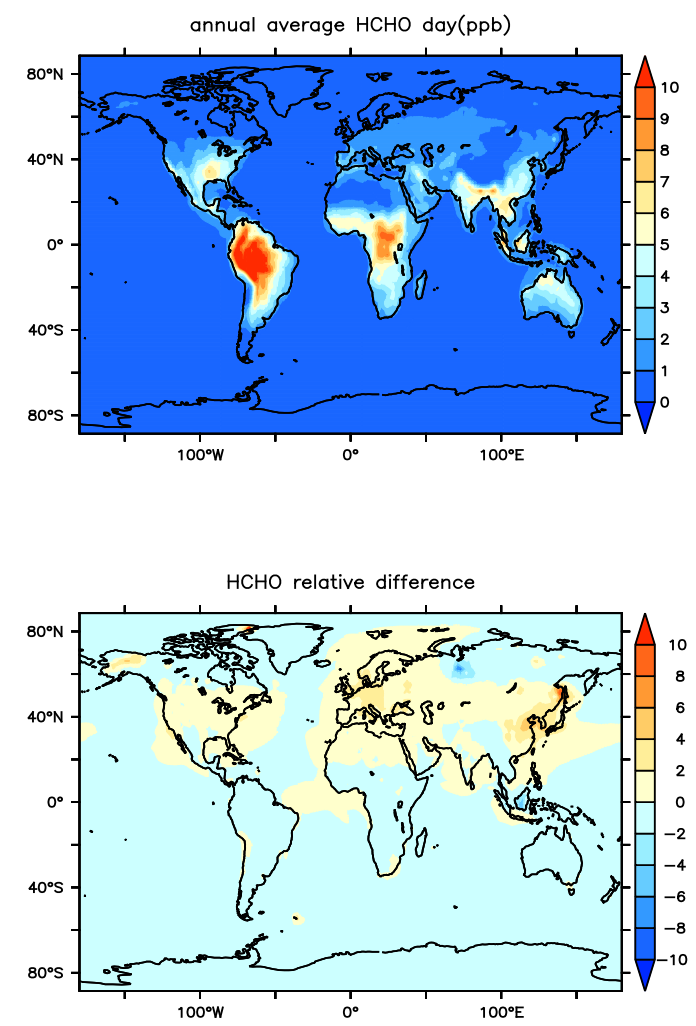

Figure 9. Top. Annual average surface mixing ratios of $\mathrm{HCHO}$ in ppt. Bottom, relative difference in \%.

America. In Europe and the US, surface mixing ratios increased up to 6\%. In oceanic areas changes remain below $2 \%$. The increases can be explained by the number of reactions leading to $\mathrm{HNO}_{3}$ formation (e.g. the reactions of xylenes, trimethyl benzenes or ethylbenzene with $\mathrm{NO}_{3}$ form $\mathrm{HNO}_{3}$ ).

\subsection{VOC}

\subsubsection{Formaldehyde}

310 The main photochemical source of formaldehyde in the background troposphere is methane oxidation; in continental areas, VOC (including aromatic compounds) oxidation is the main source, and its main sink is reactions with $\mathrm{OH}$. Comparing our two scenarios, we find a depletion in the formaldehyde surface mixing ratios (on an annual basis) in the Amazonian and central African regions-two areas that typically have higher formaldehyde mixing ratios (Figure 9). In contrast, we observed in- 
Atmos. Chem. Phys. Discuss., https://doi.org/10.5194/acp-2017-928

Manuscript under review for journal Atmos. Chem. Phys.

Discussion started: 27 October 2017

(c) Author(s) 2017. CC BY 4.0 License.
Atmospheric

Chemistry

and Physics

Discussions

(c) (1)
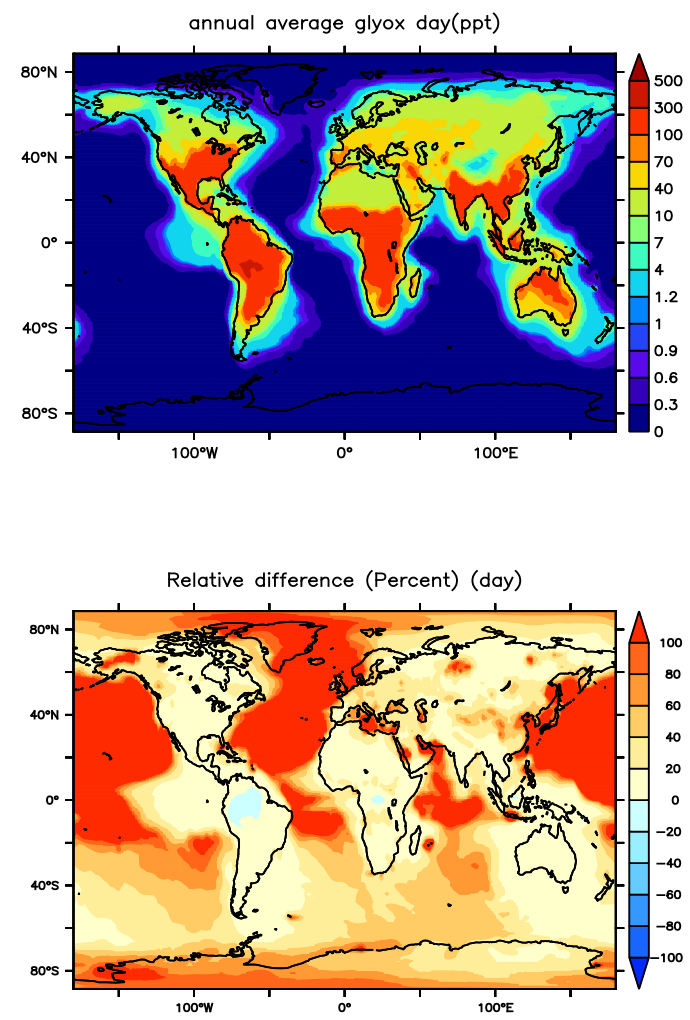

Figure 10. Top. Annual average surface mixing ratios of glyoxal in ppt. Bottom, relative difference in $\%$

creases of up to $6 \%$ in these mixing ratios in China and Europe. On the global level there is a decrease in the atmospheric burden of formaldehyde of $1.6 \%$. These changes in the formaldehyde distribution can be explained by changes in the $\mathrm{OH}$ mixing ratios, as well as the formaldehyde production from the aromatic oxidation. For instance, large urban areas have high levels of aromatics, which leads to increases in formaldehyde formation. In regions where aromatics deplete $\mathrm{OH}$, methane and other VOCs then form less formaldehyde.

\subsubsection{Glyoxal}

With respect to glyoxal, we find a global increase of $20 \%$ of the simulated mixing ratios at the surface. At the regional scale, China has the strongest absolute difference, with an increase of approximately $70 \mathrm{ppt}(80 \%)$; followed by India and the Arabian Peninsula, where increases rise by more than 40 ppt. In Figure 10 (bottom), increases larger than $100 \%$ can be seen in oceanic ar- 

In continental areas over the northern hemisphere, increases of more than $10 \%$ are found. Relative increases are lower in the southern hemisphere than in the northern hemisphere, because the main source of glyoxal in the southern hemisphere is isoprene (Fu et al., 2008). Only in some regions of Africa and the Amazon a decrease (less than 2\%) was observed; this was caused by a depletion of $\mathrm{OH}$, and by isoprene being almost the only source of glyoxal. The atmospheric burden of glyoxal is subject to a net increase of approximately $10 \%$. Nevertheless, the burden (62 Gg in the REF scenario) seems to be much larger than in Fu et al. (2008); Myriokefalitakis et al. (2008) (15-20 $\mathrm{Gg}$ ). This discrepancy is attributed to the missing mechanism of SOA formation, which has been estimated to account for approximately $20 \%$ of the total atmospheric sink (Stavrakou et al., 2009).

\subsubsection{Carbon monoxide}

The reaction chain in the oxidative process of aromatics produces carbon monoxide (CO), a relatively long-lived molecule (1-2 months). CO can travel long distances from its source, although this lifetime is not long enough to allow it to cross hemispheres (Daniel and Solomon, 1998). CO mixing ratios generally increase on the global scale, indicating a small addition to the carbon budget. When comparing both scenarios, we find an increase of $3 \%$ in the atmospheric burden of CO, which corresponds to an increase of $14 \mathrm{Tg}$. The $\mathrm{CO}$ burden estimated by the model in the REF scenario is $546 \mathrm{Tg}$.

\section{Sources of uncertainty}

345 There are a number of sources of uncertainty in the estimation of the impact of aromatics on tropospheric chemistry. Firstly, emissions of aromatics have high uncertainties. One reason is that few databases provide anthropogenic speciation of aromatic VOCs. In the case of the RCP database (van Vuuren et al., 2008), speciation entails fractioning the total VOC flux into different species (a top-down approach) (Moss et al., 2008). In the case of biomass burning emissions, information regarding the emission factors for each vegetation type is not always available for all species, and when available the variability is large (e.g. emission factor for tropical forest emissions of benzene is $0.39 \pm 0.16 \mathrm{~g} / \mathrm{kg}$ ). With regard to biogenic emissions in the present study, only toluene was included, despite that this source is of minor relevance as compared to other sources. The emissions fluxes calculated by the MEGAN model are strongly dependent on input data: e.g., on temperature or incoming radiation (Guenther et al., 2012). The model calculates a difference of $15 \%$ in the total emissions between the T42 and T106 resolutions. Interannual variability of toluene is estimated to be $6 \%$ of the total annual emissions (Sindelarova et al., 2014).

Atmospheric changes produced by aromatics are strongly dependent on $\mathrm{NO}_{\mathrm{x}}$ mixing ratios. The model tendency to underestimate $\mathrm{NO}_{\mathrm{x}}$ mixing ratios is small (Jöckel et al., 2006), but this is a 
possible source for underestimating ozone formation. Finally, it must be stressed that the EMAC model overestimates ozone mixing ratios (Jöckel et al., 2006).

Another source of error is due to the chemical oxidation mechanism (based on MCMv3.1), which in general overestimates peak ozone mixing ratios (e.g. by more than $15 \%$ in the case of toluene), and underestimates $\mathrm{OH}$ formation (up to $80 \%$ ) and $\mathrm{NO}$ oxidation rates Bloss et al. (2005). In the case of $\mathrm{OH}$, our version of the chemical mechanism includes HONO formation channels from nitrophenol photolysis, which contributes to $\mathrm{OH}$ formation during daytime.

In the mechanism used in this work, the oxidation of benzene and toluene was taken from MCM. For the rest of the aromatics that were included, the second oxidation products are directly linked to those of toluene. This approximation implies a less accurate representation of the oxidation of these species. Consequently, a comparison of simulation results with observations show relatively good agreement for benzene and toluene, although the model has difficulty reproducing xylene mixing ratios (Cabrera-Perez et al., 2016).

The largest uncertainty was generated by the treatment of SOA formation. Although approximately $23 \%$ of the aromatics emissions lead to SOA (similar to the $18 \%$ estimated by Henze et al. (2008), there are uncertainties with regards the use of the yields from $\mathrm{Ng}$ et al. (2007) to simulate real atmospheric conditions, as discussed in Henze et al. (2008). We consider it to be a plausible assumption that the channels for SOA formation occur after the first oxidation step, although this assumption implies that all secondary reactions are equally affected. However, it is hard to estimate whether this methodological choice leads to an underestimation or overestimation of the effects of aromatic compounds on atmospheric species.

\section{Summary}

This work investigated the effect of aromatic compounds on the chemistry of the troposphere at the global scale, with the help of the global circulation atmospheric chemistry model EMAC. A baseline case scenario and a sensitivity run were compared, with the first excluding aromatic compound emissions and second including them. To accurately describe the oxidation chain of the species involved (all simple monocycle aromatic compounds) we used a detailed chemical mechanism based on MCM.

At the global scale, $\mathrm{OH}$ concentrations decrease by $2-3 \%$ once aromatics are included. On the regional scale, areas with high levels of aromatics have decreases of more than $10 \%$, while regions with large $\mathrm{NO}_{\mathrm{x}}$ mixing ratios show increases of up to $10 \%$. This decrease in $\mathrm{OH}$ mixing ratios can alter the VOC distribution. For example, the formaldehyde atmospheric burden decreases by $1.2 \%$. For ozone similar results to those of $\mathrm{OH}$ are found, with a global net decrease of $1 \%$. However, the relative importance of aromatics at the regional scale can cause increases or decreases of more than $10 \%$ during the winter season. 
Atmos. Chem. Phys. Discuss., https://doi.org/10.5194/acp-2017-928

Manuscript under review for journal Atmos. Chem. Phys.

Discussion started: 27 October 2017

(c) Author(s) 2017. CC BY 4.0 License.

(c) (i)

When aromatic compounds are included, increases in carbon-containing compound emissions add to the carbon monoxide burden. In the case of glyoxal, an increase of $20 \%$ in the mixing ratios was calculated. This increase in the carbon-containing compounds explains the net decrease in $\mathrm{OH}$ concentrations over remote regions.

An important outcome is that aromatics have a larger impact in the $\mathrm{NO}_{\mathrm{x}}$ than the $\mathrm{HO}_{\mathrm{x}}$ budget.

$400 \mathrm{NO}_{2}$ is depleted due to reaction of nitrogen compounds with aromatics, with this nitrogen being deposited more efficiently. In contrast, the $\mathrm{NO}_{3}$ atmospheric burden increases by $6 \%$, with changes by more than $30 \%$ in several areas of the northern hemisphere. Aromatics can thus be important for nighttime chemistry. The depletion of $\mathrm{NO}_{\mathrm{x}}$ in combination with the increase in $\mathrm{CO}$ leads to $\mathrm{OH}$ depletion.

405 We conclude that, although aromatic compound chemistry at the global scale has a relatively minor impact, at a regional scale, the influence of aromatics in the troposphere can be important, and can be responsible for relatively large changes in $\mathrm{OH}$, ozone, and especially glyoxal and $\mathrm{NO}_{3}$. We therefore recommend including detailed aromatic chemistry in regional and global model simulations.

410 Acknowledgements. The authors want to acknowledge the use of the Ferret program for analysis and graphics in this paper. Ferret is a product of NOAA's Pacific Marine Environmental Laboratory (information is available at http://www.ferret.noaa.gov). 
Atmos. Chem. Phys. Discuss., https://doi.org/10.5194/acp-2017-928

Manuscript under review for journal Atmos. Chem. Phys.

Discussion started: 27 October 2017

(c) Author(s) 2017. CC BY 4.0 License.

\section{References}

Atkinson, R.: Atmospheric chemistry of VOCs and $\mathrm{NO}_{x}$, Atmospheric environment, 34, 2063-2101, 2000.

Atkinson, R., Aschmann, S. M., Arey, J., and Carter, W. P.: Formation of ring-retaining products from the OH radical-initiated reactions of benzene and toluene, International Journal of Chemical Kinetics, 21, 801-827, 1989.

Baker, A. K., Beyersdorf, A. J., Doezema, L. A., Katzenstein, A., Meinardi, S., Simpson, I. J., Blake, D. R., and Rowland, F. S.: Measurements of nonmethane hydrocarbons in 28 United States cities, Atmospheric Environment, 42, 170-182, 2008.

Barletta, B., Meinardi, S., Sherwood Rowland, F., Chan, C.-Y., Wang, X., Zou, S., Yin Chan, L., and Blake, D. R.: Volatile organic compounds in 43 Chinese cities, Atmospheric Environment, 39, 5979-5990, 2005.

Bejan, I., El Aal, Y. A., Barnes, I., Benter, T., Bohn, B., Wiesen, P., and Kleffmann, J.: The photolysis of ortho-nitrophenols: a new gas phase source of HONO, Physical Chemistry Chemical Physics, 8, 2028-2035, 2006.

Bloss, C., Wagner, V., Jenkin, M. E., Volkamer, R., Bloss, W. J., Lee, J. D., Heard, D. E., Wirtz, K., MartinReviejo, M., Rea, G., Wenger, J. C., and Pilling, M. J.: Development of a detailed chemical mechanism (MCMv3.1) for the atmospheric oxidation of aromatic hydrocarbons, Atmospheric Chemistry and Physics, 5, 641-664, doi:10.5194/acp-5-641-2005, https://www.atmos-chem-phys.net/5/641/2005/, 2005.

Butler, T., Lawrence, M., Taraborrelli, D., and Lelieveld, J.: Multi-day ozone production potential of volatile organic compounds calculated with a tagging approach, Atmospheric Environment, 45, 4082-4090, 2011.

Cabrera-Perez, D., Taraborrelli, D., Sander, R., and Pozzer, A.: Global atmospheric budget of simple monocyclic aromatic compounds, Atmospheric Chemistry and Physics Discussions, 2016, 1-25, doi:10.5194/acp2015-996, http://www.atmos-chem-phys-discuss.net/acp-2015-996/, 2016. a combined experimental and theoretical investigation., The Journal of chemical physics, 130, $234311-$ $234311,2009$.

Crutzen, P. J. and Zimmermann, P. H.: The changing photochemistry of the troposphere, Tellus B, 43, 136-151, 1991.

440 Daniel, J. S. and Solomon, S.: On the climate forcing of carbon monoxide, Journal of Geophysical Research: Atmospheres, 103, 13 249-13 260, 1998.

Deckert, R., Jöckel, P., Grewe, V., Gottschaldt, K.-D., and Hoor, P.: A quasi chemistry-transport model mode for EMAC, Geoscientific Model Development, 4, 195-206, 2011.

Finlayson-Pitts, B. J. and Pitts, J. N.: Tropospheric air pollution: ozone, airborne toxics, polycyclic aromatic hydrocarbons, and particles, Science, 276, 1045-1051, 1997.

Finlayson-Pitts, B. J. and Pitts Jr, J. N.: Atmospheric chemistry. Fundamentals and experimental techniques, John Wiley and Sons, New York, NY, 1986.

Forster, P., Ramaswamy, V., Artaxo, P., Berntsen, T., Betts, R., Fahey, D. W., Haywood, J., Lean, J., Lowe, D. C., Myhre, G., Nganga, J., Prinn, R., Raga, G., Schulz, M., and Van Dorland, R.: Changes in atmospheric constituents and in radiative forcing. Chapter 2, in: Climate Change 2007. The Physical Science Basis, 2007. 
Atmos. Chem. Phys. Discuss., https://doi.org/10.5194/acp-2017-928

Manuscript under review for journal Atmos. Chem. Phys.

Discussion started: 27 October 2017

(c) Author(s) 2017. CC BY 4.0 License.

Fu, T.-M., Jacob, D. J., Wittrock, F., Burrows, J. P., Vrekoussis, M., and Henze, D. K.: Global budgets of atmospheric glyoxal and methylglyoxal, and implications for formation of secondary organic aerosols, Journal of Geophysical Research: Atmospheres (1984-2012), 113, 2008.

Guenther, A. B., Jiang, X., Heald, C. L., Sakulyanontvittaya, T., Duhl, T., Emmons, L. K., and Wang, X.: The Model of Emissions of Gases and Aerosols from Nature version 2.1 (MEGAN2.1): an extended and updated framework for modeling biogenic emissions, Geoscientific Model Development, 5, 1471-1492, doi:10.5194/gmd-5-1471-2012, http://www.geosci-model-dev.net/5/1471/2012/, 2012.

Henze, D., Seinfeld, J., Ng, N., Kroll, J., Fu, T.-M., Jacob, D. J., and Heald, C.: Global modeling of secondary organic aerosol formation from aromatic hydrocarbons: high-vs. low-yield pathways, Atmospheric Chemistry and Physics, 8, 2405-2420, 2008.

Jagiella, S. and Zabel, F.: Reaction of phenylperoxy radicals with NO 2 at 298 K, Physical Chemistry Chemical Physics, 9, 5036-5051, 2007.

Jenkin, M., Saunders, S., Wagner, V., and Pilling, M.: Protocol for the development of the Master Chemical Mechanism, MCM v3 (Part B): tropospheric degradation of aromatic volatile organic compounds, Atmospheric Chemistry and Physics, 3, 181-193, 2003.

Jöckel, P., Tost, H., Pozzer, A., Brühl, C., Buchholz, J., Ganzeveld, L., Hoor, P., Kerkweg, A., Lawrence, M. G., Sander, R., Steil, B., Stiller, G., Tanarhte, M., Taraborrelli, D., van Aardenne, J., and Lelieveld, J.: The atmospheric chemistry general circulation model ECHAM5/MESSy1: consistent simulation of ozone from the surface to the mesosphere, Atmospheric Chemistry and Physics, 6, 5067-5104, doi:10.5194/acp-6-50672006, https://www.atmos-chem-phys.net/6/5067/2006/, 2006.

Jöckel, P., Kerkweg, A., Pozzer, A., Sander, R., Tost, H., Riede, H., Baumgaertner, A., Gromov, S., and Kern, B.: Development cycle 2 of the modular earth submodel system (MESSy2), Geoscientific Model Development, 3, 717-752, 2010.

Kaiser, J. W., Heil, A., Andreae, M. O., Benedetti, A., Chubarova, N., Jones, L., Morcrette, J.-J., Razinger, M.,

Schultz, M. G., Suttie, M., and van der Werf, G. R.: Biomass burning emissions estimated with a global fire assimilation system based on observed fire radiative power, Biogeosciences, 9, 527-554, doi:10.5194/bg-9527-2012, https://www.biogeosciences.net/9/527/2012/, 2012.

Kleinman, L. I.: Low and high NOx tropospheric photochemistry, Journal of Geophysical Research: Atmospheres, 99, 16831-16838, 1994.

Koppmann, R.: Volatile organic compounds in the atmosphere, John Wiley \& Sons, 2008.

Lawrence, M., Jöckel, P., and Kuhlmann, R. v.: What does the global mean OH concentration tell us?, Atmospheric Chemistry and Physics, 1, 37-49, 2001.

Lee, S., Chiu, M., Ho, K., Zou, S., and Wang, X.: Volatile organic compounds (VOCs) in urban atmosphere of Hong Kong, Chemosphere, 48, 375-382, 2002.

Lelieveld, J. and Dentener, F. J.: What controls tropospheric ozone?, Journal of Geophysical Research: Atmospheres, 105, 3531-3551, 2000 .

Lelieveld, J., Evans, J., Fnais, M., Giannadaki, D., and Pozzer, A.: The contribution of outdoor air pollution sources to premature mortality on a global scale, Nature, 525, 367-371, 2015. 
Lelieveld, J., Gromov, S., Pozzer, A., and Taraborrelli, D.: Global tropospheric hydroxyl distribution, budget and reactivity, Atmospheric Chemistry and Physics, 16, 12 477-12493, doi:10.5194/acp-16-12477-2016, http://www.atmos-chem-phys.net/16/12477/2016/, 2016.

Levy, H.: Normal atmosphere: Large radical and formaldehyde concentrations predicted, Science, 173, 141143, 1971.

Lightfoot, P. D., Cox, R., Crowley, J., Destriau, M., Hayman, G., Jenkin, M., Moortgat, G., and Zabel, F.: Organic peroxy radicals: kinetics, spectroscopy and tropospheric chemistry, Atmospheric Environment. Part A. General Topics, 26, 1805-1961, 1992.

Misztal, P., Hewitt, C., Wildt, J., Blande, J., Eller, A., Fares, S., Gentner, D., Gilman, J., Graus, M., Greenberg, J., Guenther, A., Hansel, A., Harley, P., Huang, M., Jardine, K., Karl, T., Kaser, L., Keutsch, F., KiendlerScharr, A., Kleist, E., Lerner, B., Li, T., Mak, J., Nölscher, A., Schnitzhofer, R., Sinha, V., Thornton, B., Warneke, C., Wegener, F., Werner, C., Williams, J., Worton, D., Yassaa, N., and Goldstein, A.: 5, 12 064-, http://dx.doi.org/10.1038/srep12064, 2015.

Montzka, S. A., Krol, M., Dlugokencky, E., Hall, B., Jöckel, P., and Lelieveld, J.: Small interannual variability of global atmospheric hydroxyl, Science, 331, 67-69, 2011.

Moss, R. H., Nakicenovic, N., and O’Neill, B.: Towards new scenarios for analysis of emissions, climate change, impacts, and response strategies, 2008.

Myriokefalitakis, S., Vrekoussis, M., Tsigaridis, K., Wittrock, F., Richter, A., Brühl, C., Volkamer, R., Burrows, J., and Kanakidou, M.: The influence of natural and anthropogenic secondary sources on the glyoxal global distribution, Atmospheric Chemistry and Physics, 8, 4965-4981, 2008.

Ng, N., Kroll, J., Chan, A., Chhabra, P., Flagan, R., and Seinfeld, J.: Secondary organic aerosol formation from m-xylene, toluene, and benzene, Atmospheric Chemistry and Physics, 7, 3909-3922, 2007.

Odum, J. R., Hoffmann, T., Bowman, F., Collins, D., Flagan, R. C., and Seinfeld, J. H.: Gas/Particle Partitioning and Secondary Organic Aerosol Yields, Environmental Science \& Technology, 30, 2580-2585, doi:10.1021/es950943+, http://dx.doi.org/10.1021/es950943+, 1996.

Pozzer, A., Jöckel, P., Tost, H., Sander, R., Ganzeveld, L., Kerkweg, A., and Lelieveld, J.: Simulating organic species with the global atmospheric chemistry general circulation model ECHAM5/MESSy1: a comparison of model results with observations, Atmospheric Chemistry and Physics, 7, 2527-2550, 2007.

Pozzer, A., Jöckel, P., and Aardenne, J. V.: The influence of the vertical distribution of emissions on tropospheric chemistry, Atmospheric Chemistry and physics, 9, 9417-9432, 2009.

Pozzer, A., Pollmann, J., Taraborrelli, D., Joeckel, P., Helmig, D., Tans, P., Hueber, J., and Lelieveld, J.: Observed and simulated global distribution and budget of atmospheric $\mathrm{C}_{2}-\mathrm{C}_{5}$ alkanes, Atmospheric Chemistry and Physics, 10, 4403-4422, 2010.

Prather, M. and Spivakovsky, C. M.: Tropospheric $\mathrm{OH}$ and the lifetimes of hydrochlorofluorocarbons, Journal of Geophysical Research: Atmospheres, 95, 18 723-18 729, 1990.

Ran, L., Zhao, C., Geng, F., Tie, X., Tang, X., Peng, L., Zhou, G., Yu, Q., Xu, J., and Guenther, A.: Ozone 
Atmos. Chem. Phys. Discuss., https://doi.org/10.5194/acp-2017-928

Manuscript under review for journal Atmos. Chem. Phys.

Discussion started: 27 October 2017

(c) Author(s) 2017. CC BY 4.0 License.

Roeckner, E., Brokopf, R., Esch, M., Giorgetta, M., Hagemann, S., Kornblueh, L., Manzini, E., Schlese, U., and Schulzweida, U.: Sensitivity of simulated climate to horizontal and vertical resolution in the ECHAM5 atmosphere model, Journal of Climate, 19, 3771-3791, 2006.

Sack, T. M., Steele, D. H., Hammerstrom, K., and Remmers, J.: A survey of household products for volatile organic compounds, Atmospheric Environment. Part A. General Topics, 26, 1063-1070, 1992.

Sander, R., Baumgaertner, A., Gromov, S., Harder, H., Jöckel, P., Kerkweg, A., Kubistin, D., Regelin, E., Riede, H., Sandu, A., Taraborrelli, D., Tost, H., and Xie, Z.-Q.: The atmospheric chemistry box model CAABA/MECCA-3.0, Geosci. Model Dev., 4, 373-380, http://www.geosci-model-dev.net/4/373, 2011.

Sindelarova, K., Granier, C., Bouarar, I., Guenther, A., Tilmes, S., Stavrakou, T., Müller, J.-F., Kuhn, U., Stefani, P., and Knorr, W.: Global data set of biogenic VOC emissions calculated by the MEGAN model over the last 30 years, Atmospheric Chemistry and Physics, 14, 9317-9341, doi:10.5194/acp-14-9317-2014, https: //www.atmos-chem-phys.net/14/9317/2014/, 2014.

Stavrakou, T., Müller, J.-F., Smedt, I. D., Roozendael, M. V., Van der Werf, G., Giglio, L., and Guenther, A.: Evaluating the performance of pyrogenic and biogenic emission inventories against one decade of spacebased formaldehyde columns, Atmospheric Chemistry and Physics, 9, 1037-1060, 2009.

Stevenson, D. S., Dentener, F. J., Schultz, M. G., Ellingsen, K., van Noije, T. P. C., Wild, O., Zeng, G., Amann, M., Atherton, C. S., Bell, N., Bergmann, D. J., Bey, I., Butler, T., Cofala, J., Collins, W. J., Derwent, R. G., Doherty, R. M., Drevet, J., Eskes, H. J., Fiore, A. M., Gauss, M., Hauglustaine, D. A., Horowitz, L. W., Isaksen, I. S. A., Krol, M. C., Lamarque, J.-F., Lawrence, M. G., Montanaro, V., Müller, J.-F., Pitari, G., Prather, M. J., Pyle, J. A., Rast, S., Rodriguez, J. M., Sanderson, M. G., Savage, N. H., Shindell, D. T., Strahan, S. E., Sudo, K., and Szopa, S.: Multimodel ensemble simulations of present-day and near-future tropospheric ozone, Journal of Geophysical Research: Atmospheres, 111, n/a-n/a, doi:10.1029/2005JD006338, http://dx.doi.org/10.1029/2005JD006338, d08301, 2006.

van Vuuren, D. P., Feddema, J., Lamarque, J.-F., Riahi, K., Rose, S., Smith, S., and Hibbard, K.: Work plan for data exchange between the integrated assessment and climate modeling community in support of phase- 0 of scenario analysis for climate change assessment (representative community pathways), assessment (Representative Community Pathways), 3, 4, 2008.

van Vuuren, D. P., Edmonds, J., Kainuma, M., Riahi, K., Thomson, A., Hibbard, K., Hurtt, G. C., Kram, T., Krey, V., Lamarque, J.-F., Masui, T., Meinshausen, M., Nakicenovic, N., Smith, S. J., and Rose, S. K.: The representative concentration pathways: an overview, Climatic Change, 109, 5, doi:10.1007/s10584-0110148-z, https://doi.org/10.1007/s10584-011-0148-z, 2011.

Voulgarakis, A., Naik, V., Lamarque, J.-F., Shindell, D. T., Young, P. J., Prather, M. J., Wild, O., Field, R. D., Bergmann, D., Cameron-Smith, P., Cionni, I., Collins, W. J., Dalsøren, S. B., Doherty, R. M., Eyring, V., Faluvegi, G., Folberth, G. A., Horowitz, L. W., Josse, B., MacKenzie, I. A., Nagashima, T., Plummer, D. A., Righi, M., Rumbold, S. T., Stevenson, D. S., Strode, S. A., Sudo, K., Szopa, S., and Zeng, G.: Analysis of present day and future $\mathrm{OH}$ and methane lifetime in the ACCMIP simulations, Atmospheric Chemistry and Physics, 13, 2563-2587, doi:10.5194/acp-13-2563-2013, https://www.atmos-chem-phys.net/13/2563/2013/, 2013. 
Atmos. Chem. Phys. Discuss., https://doi.org/10.5194/acp-2017-928

Manuscript under review for journal Atmos. Chem. Phys.

Discussion started: 27 October 2017

(c) Author(s) 2017. CC BY 4.0 License.

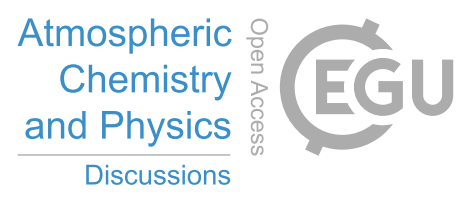

(c) (1)

Ziemann, P. J. and Atkinson, R.: Kinetics, products, and mechanisms of secondary organic aerosol formation, Chemical Society Reviews, 41, 6582-6605, 2012.

Zou, S., Lee, S., Chan, C., Ho, K., Wang, X., Chan, L., and Zhang, Z.: Characterization of ambient volatile organic compounds at a landfill site in Guangzhou, South China, Chemosphere, 51, 1015-1022, 2003. 